\title{
Distributions of larval rockfishes Sebastes spp. across nearshore fronts in a coastal upwelling region
}

\author{
Eric P. Bjorkstedt ${ }^{1,2, *}$, Leslie K. Rosenfeld ${ }^{3, * *}$, Brian A. Grantham ${ }^{1, * * *}$, \\ Yehoshua Shkedy ${ }^{1, * * *}$, Joan Roughgarden ${ }^{1,4}$ \\ ${ }^{1}$ Department of Biological Sciences, Stanford University, Stanford, California 94305, USA \\ ${ }^{2}$ National Oceanic and Atmospheric Administration (NOAA) Fisheries, Santa Cruz Laboratory, 110 Shaffer Road, Santa Cruz, \\ California 95060, USA \\ ${ }^{3}$ Monterey Bay Aquarium Research Institute, Pacific Grove, California 93935, USA \\ ${ }^{4}$ Department of Geophysics, Stanford University, Stanford, California 94305, USA
}

\begin{abstract}
We sampled larval fishes along cross-shelf transects off Granite Canyon, California, USA, during the upwelling seasons of 1993 and 1994 to determine whether coastal upwelling fronts affect the cross-shelf distribution of larval rockfishes Sebastes spp. during the earliest period of planktonic life. Rockfish larvae occurred in relatively high densities near surface fronts and were distributed in patches oriented along sloping pycnoclines contiguous with surface fronts. Qualitative comparisons between observed distributions of larval rockfishes in relation to hydrographic structure and predictions from models of plankton distributions at convergent fronts support the hypothesis that convergent circulation contributes to observed distributions. Our results indicate that (1) coastal upwelling fronts influence larval rockfishes at an earlier life history stage than has previously been documented, and (2) the influence of upwelling fronts on distributions of larval rockfishes is similar to the influence of hydrographic fronts on distributions of larval fish reported for a variety of oceanographic settings. In light of the plausible effects of upwelling fronts on larval transport and ecology, our findings suggest that upwelling fronts merit further investigation for their potential role in translating variability in upwelling dynamics into fluctuations in recruitment to coastal rockfish populations along the west coast of North America.
\end{abstract}

KEY WORDS: Larval fish distribution - Coastal upwelling - Upwelling fronts · Recruitment mechanisms $\cdot$ Rockfishes $\cdot$ Sebastes

\section{INTRODUCTION}

Wind-driven upwelling exerts a strong influence on the productivity and circulation of the coastal ocean in eastern boundary current systems (Brink \& Cowles

\footnotetext{
${ }^{*}$ Correspondence address: Santa Cruz.

E-mail: eric.bjorkstedt@noaa.gov

Present addresses:

**Naval Postgraduate School, Code OC/Ro, Monterey, California 93943, USA

*** Department of Zoology, Cordley 3029, Oregon State University, Corvallis, Oregon 97331, USA

${ }^{* * * *}$ Israel Nature and Parks Authority, 3 Am Veolamo Street, Jerusalem 95463, Israel
}

1991). Variability in recruitment of coastal fishes and invertebrates that undergo a planktonic larval phase has been linked to variability in upwelling intensity over a range of spatial and temporal scales (Bailey 1981, Cury \& Roy 1989, Farrell et al. 1991, Roughgarden et al. 1991, Ainley et al. 1993, Lenarz et al. 1995, Ralston 1995, Ralston \& Howard 1995, Shkedy et al. 1995, Wing et al. 1995a,b, Morgan et al. 2000).

Among the taxa affected by upwelling, rockfishes Sebastes spp. exhibit early life histories that are in many ways functionally intermediate to life histories typified by intertidal invertebrates and coastal pelagic fishes: like pelagic fishes, rockfishes undergo substantial growth and development in the pelagic habitat, 
developing from small ( 3 to $7 \mathrm{~mm}$ ) larvae into pelagic juveniles 20 to $70 \mathrm{~mm}$ in length prior to settlement to benthic habitats, yet, like intertidal invertebrates, many species of rockfishes must return to nearshore habitats to complete the life cycle (Love et al. 1991, Moser \& Boehlert 1991). Empirical relationships between rockfish recruitment and upwelling intensity (Norton 1987, Ainley et al. 1993, Ralston \& Howard 1995) exhibit characteristics of both dome-shaped relations indicative of optimal conditions for larval feeding (Cury \& Roy 1989), and inverse relations indicative of the effects of transport on larval supply to adult habitats (Farrell et al. 1991, Roughgarden et al. 1991, Shkedy et al. 1995, Wing et al. 1995a,b). Presently, however, little is known about specific mechanisms through which variability in upwelling might translate into recruitment variability.

Hydrographic fronts have been hypothesized to have an important role in determining recruitment to fish populations, presumably through their influence on larval ecology and transport (Grimes \& Kingsford 1996). Densities of larval fishes in frontal zones are commonly greater than in adjacent water masses, although specific distributions vary considerably among taxa (Kiørboe et al. 1988, Grimes \& Finucane 1991, Kingsford et al. 1991, Govoni \& Grimes 1992, Munk et al. 1995, Kingsford \& Suthers 1996a, Sabatés \& Olivar 1996, Lochmann et al. 1997). Plausible mechanisms for the generation and maintenance of elevated densities of larval fishes at fronts include (1) concentrated spawning in frontal zones (Shelton \& Hutchings 1982), (2) concentration of larvae by hydrodynamic convergence at fronts (Govoni \& Grimes 1992, Lochmann et al. 1997), and (3) improved feeding success, condition and growth deriving from elevated productivity at fronts (Munk 1993, Lang et al. 1994, St John \& Lund 1996; see Powell et al. 1990 for an exception) which might abbreviate periods of vulnerability to predation (Meekan \& Fortier 1996). However, notwithstanding the potential benefits for larvae at fronts of improved feeding success and partial protection in a dense field of alternative prey (Kean-Howie et al. 1988), increased predation intensity by planktivores that aggregate at fronts (Taggart et al. 1989, Sims \& Quayle 1998) can easily counteract any trophic benefits (Grimes \& Kingsford 1996, Grimes 2001). Fronts can affect recruitment by retaining larval fishes in suitable nursery grounds (Kiørboe et al. 1988, Sabatés \& Olivar 1996, Lochmann et al. 1997) or transporting larvae to such habitats (Shelton \& Hutchings 1982, Kingsford \& Suthers 1996a,b, Eggleston et al. 1998).

Upwelling fronts, which mark sharp transitions between denser (colder, saltier) upwelled water and lighter (warmer, fresher) oceanic water, might play a similar role in the ecology of rockfishes in coastal upwelling regions. Such fronts are ubiquitous, dynamic features in the coastal ocean off central California, and typically exhibit a complex structure in response to temporal variability in upwelling-favorable winds, topographic steering of coastal winds, and bathymetric influences on coastal circulation (Brink 1983, Send et al. 1987, Batteen 1997). Upwelling fronts influence the distribution and recruitment of intertidal invertebrate larvae that rely on transport to nearshore habitats for successful settlement (Farrell et al. 1991, Roughgarden et al. 1991, Grantham 1997), and can directly or indirectly affect the distribution and transport of larval fishes (Richardson \& Pearcy 1977, Shelton \& Hutchings 1982, Graham \& Largier 1997). Local productivity maxima and elevated densities of small zooplankters often occur at upwelling fronts (Peterson et al. 1979, Dengler 1985, Traganza et al. 1987, Grantham 1997).

The role of upwelling fronts in the larval ecology of rockfish larvae has not been investigated. Large-scale, coarse-resolution ichthyoplankton surveys indicate an extensive cross-shelf distribution of larval rockfishes, and rockfish larvae are often captured hundreds of $\mathrm{km}$ out to sea (Moser et al. 1993); however, the distribution of pelagic juveniles is typically more restricted, and juveniles often occur at higher densities at or near upwelling fronts than in nearby water masses (Lenarz et al. 1991, Larson et al. 1994, Wing et al. 1998, K. Sakuma \& S. Ralston unpubl. data). Upwelling fronts might provide a suitable, perhaps even superior, habitat during the early life history of rockfishes, which invites speculation that upwelling fronts play a role in determining which larvae survive to recruitment. Not all fronts off central California are formed by coastal upwelling, particularly during the winter, yet such fronts also appear to affect distributions of rockfish larvae (Sakuma \& Ralston 1995).

An initial step toward developing and evaluating hypotheses regarding the role of upwelling fronts in the larval ecology and recruitment of rockfishes is to establish whether nearshore upwelling fronts affect rockfishes during early life history stages that are critical to determining recruitment success. In this paper, we address this issue with data on the cross-shelf distribution of larval rockfishes across frontal zones collected during the late spring and summer off central California. We conducted our study in the coastal ocean off the Big Sur Coast south of Monterey, California, which is affected strongly by the upwelling center off Point Sur and, to a lesser degree, by the southern end of the upwelling plume extending from the Point Año Nuevo upwelling center (Traganza et al. 1981, Breaker \& Broenkow 1989, Rosenfeld et al. 1994). The study region is in an area marked by a narrow continental shelf penetrated by large submarine canyons, and was negligibly affected by freshwater input during the years of our study. Upwelling dynamics and the 
formation of fronts in the Point Sur and Point Año Nuevo upwelling centers are effectively simultaneous due to large-scale coherence in temporal variability of wind stress (Rosenfeld et al. 1994). The 2 upwelling plumes can and do interact; however, even during periods of the strongest upwelling-favorable winds, a minimum of 5 to $6 \mathrm{~d}$ is required for transport of water upwelled off Point Año Nuevo across Monterey Bay and along the Big Sur coast to our study region (Breaker \& Broenkow 1989, Rosenfeld et al. 1994). In our analysis, we focus on the distribution of larval rockfishes during the very beginning of the planktonic phase in relation to the position of nearshore fronts and cross-shelf changes in the vertical structure of the water column associated with these fronts.

\section{MATERIALS AND METHODS}

Larval fishes were sampled along transects extending due west from Granite Canyon $\left(36^{\circ} 25.9^{\prime} \mathrm{N}\right.$, $121^{\circ} 55.0^{\prime} \mathrm{W}$, approximately $150 \mathrm{~km}$ south of San Francisco, California) on 4 separate cruises aboard RV 'Point Sur' during the upwelling seasons of 1993 and 1994 (Fig. 1). We used hydrographic data collected during previous transect crossings and recently collected (often quasi-synoptic) satellite AVHRR (advanced very high resolution radiometry) images of sea surface temperature to identify and select fronts for further investigation. We designed transects immediately prior to the start of sampling according to the following rules: (1) sampling was to begin as close to the coast as possible without risk to the gear, (2) stations were to be spaced at approximately $3 \mathrm{~km}$ intervals, and (3) ideally, the last (offshore) station was to be placed at least a Rossby radius (a natural scale of horizontal oceanographic structure; approximately $10 \mathrm{~km}$ in this region; Rosenfeld et al. 1994) offshore of the outermost front to be sampled. Transects thus had variable numbers of sampling stations. On each transect, sampling for larval fishes began with the station nearest to the coast, and progressed in an offshore direction. Sampling generally began during the afternoon or evening and continued into the night. Depending on the number of stations (8 to 14) in a transect, sampling required approximately 7 to $12 \mathrm{~h}$ to complete.

Physical data. At each station, a CTD (Seabird 9/11 Plus) cast to $250 \mathrm{~m}$ depth (or as limited by bathymetry) directly preceded biological sampling. CTD data were processed as described in Rosenfeld et al. (1995) to generate temperature, salinity, and density data with $1 \mathrm{~m}$ vertical resolution beginning at a depth of $4 \mathrm{~m}$. Near-surface (approximately $3 \mathrm{~m}$ depth) temperature and salinity were measured at $30 \mathrm{~s}$ intervals with the ship's flowthrough system. Temperature and salinity data were converted to density according to the IES 80 equation for density with no correction for pressure (JPOTS 1991).

Hydrographic cross-sections were generated from CTD profiles using contouring functions in MATLAB (Version 6.0; available at: www.mathworks.com). Surface density along each transect was smoothed by fitting a locally weighted, robust linear function (the 'lowess' function from S-Plus 3.0; available at: www. mathsoft.com) over a moving window that spanned approximately $3 \mathrm{~km}_{\text {i }}$ surface density gradients were calculated from the resulting smoothed curve. We identified fronts as locally strong gradients in surface density that were clearly associated with shoaling isopycnals. Surface density-gradient minima (large negative values) indicated fronts between colder, saltier water nearshore and warmer, fresher water offshore.

Satellite AVHRR images and wind data collected over the 3 to $6 \mathrm{wk}$ preceding a cruise were used to characterize upwelling conditions leading up to sample collection. Hourly wind measurements (averaged over an 8 min period) were obtained from National Data Buoy Center (NDBC) Buoy 46042 located at $36^{\circ} 45^{\prime} \mathrm{N}$, $122^{\circ} 24^{\prime} \mathrm{W}$, approximately $70 \mathrm{~km}$ northwest of Granite Canyon (data available at http://seaboard.ndbc.noaa. gov/data/dataindex.shtml). During each cruise, observations of sea surface temperature from satellite-based AVHRR sensors aboard NOAA satellites (NOAA-11, -12 , and -14) were obtained and processed remotely, and retrieved while at sea for use in planning transects.

Biological data. Larval fishes were captured with a Tucker trawl ( $1 \mathrm{~m}^{2}$ mouth opening) with 3 openingclosing nets, each of which was fitted with $200 \mu \mathrm{m}$ mesh, a rigid cod end with $96 \mu \mathrm{m}$ mesh windows, and a General Oceanics 2030R flowmeter. At each station, we conducted a single tow of the net; we did not collect repeated samples at each station for 2 reasons: (1) repeated occupation of stations would have greatly extended the time necessary to complete a transect and further compromised our efforts to obtain a synoptic view of the distribution of larvae across frontal zones, and (2) repeated sampling at a given set of coordinates in a dynamic upwelling zone provides no guarantee of sampling the same water mass, and thus gives a false impression of replication. The trawl was towed obliquely from depth at approximately 1 to $1.5 \mathrm{~m} \mathrm{~s}^{-1}$, and nets were opened and closed during each tow to obtain discrete samples from 2 depth strata (approximately 55-27 and 27-0 m for August 1993, June and August 1994; 75-37 and 35-0 m in May 1994); actual depths fished were estimated trigonometrically from cable length and angle. We compensated for occasional flowmeter failures by estimating filtered volume from the distance the net was towed and the mean ratio between towed distance and filtration from adja- 
cent stations. Samples were preserved with 2 to $4 \%$ buffered formalin in filtered seawater and transferred to 50 to $70 \%$ ethanol upon return to the laboratory.

All larval fishes were removed from $3 / 4$ or $7 / 8$ portions of each sample and identified to the lowest possible taxonomic level according to Matarese et al. (1989); larval rockfishes were identified only to genus. Larvae were measured to the nearest $0.1 \mathrm{~mm}$ (standard or notochord length), and scored for developmental stage (pre-flexion, flexion or post-flexion: Kendall et al. 1984). No attempt was made to correct lengths for the effects of preservation (Pepin et al. 1998). Counts of larval rockfishes were converted to density (ind. per $1000 \mathrm{~m}^{3}$ ) for comparison to front structure.

The data for distributions of larval rockfishes along each transect consist of point estimates of the density of larval rockfishes by size class and depth stratum at each station. We infer relations between distributions of larval fishes and hydrographic structure by comparing the location of peak densities of larval rockfishes to the location of surface fronts, and overlaying depthstratified distributions on hydrographic sections to dis-
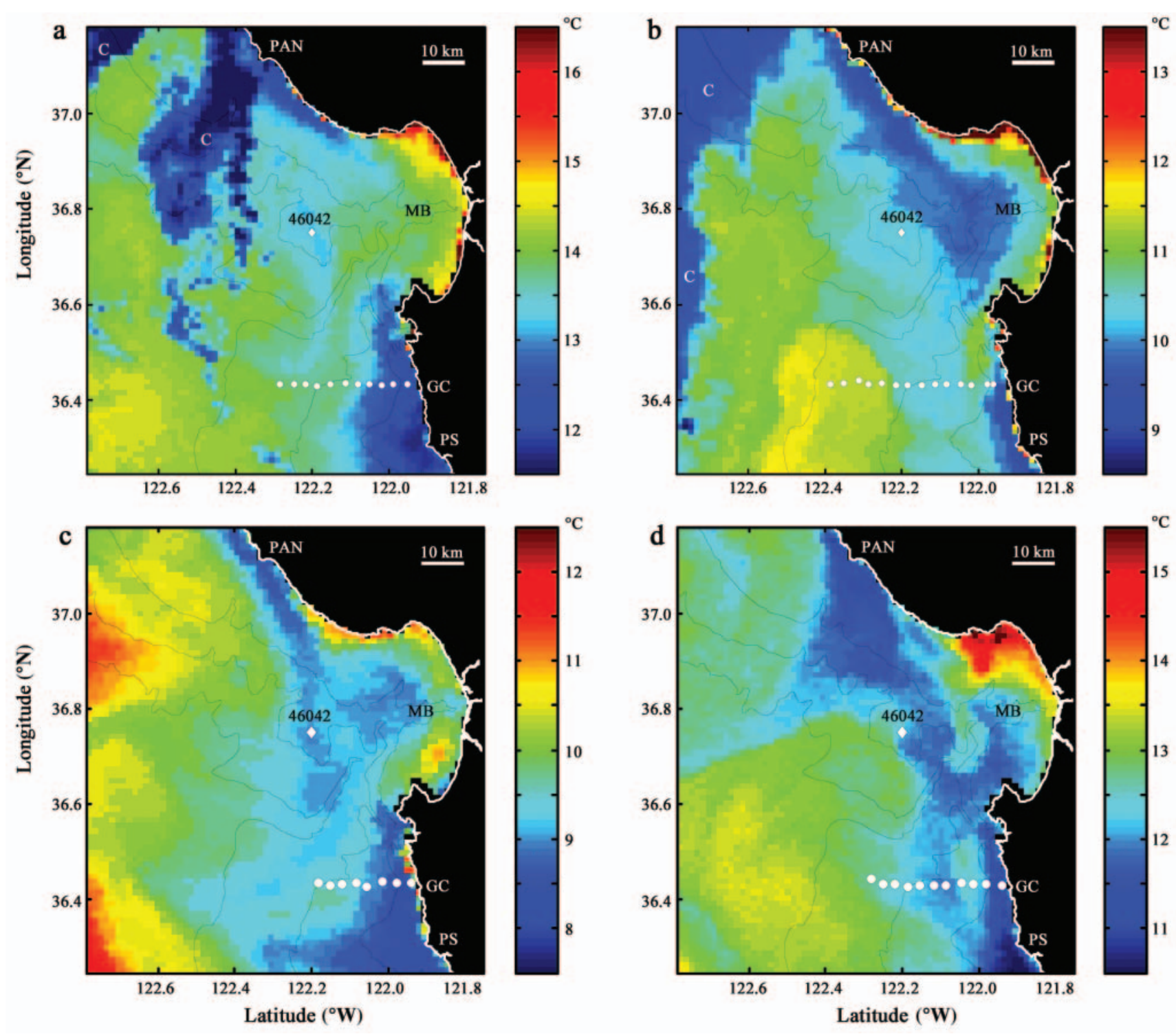

Fig. 1. Satellite AVHRR observations of sea surface temperature, and locations of sampling stations along transects off Granite Canyon, California. (a) Cruise I: 11-12 August 1993, image from approximately 16:00 h Pacific Daylight Time (PDT), 11 August 1993; (b) Cruise II: 4-5 May 1994, image from approximately 16:00 h PDT, 4 May 1994; (c) Cruise III: 26-27 June 1994, image from 06:00 h PDT, 26 June 1994; (d) Cruise IV: 4-5 August 1994, image from approximately 19:00 h PDT, 6 August 1994. Images are raw Channel 4 temperatures uncorrected for atmospheric moisture, and are intended to illustrate general structure of the coastal ocean rather than to represent accurately sea surface temperature. PAN: Point Año Nuevo; MB: Monterey Bay; GC: Granite Canyon; PS: Point Sur; C: areas masked by clouds. Contours indicate 200,1000, and $2000 \mathrm{~m}$ isobaths. Note that temperature scales are unique to each map 
cern how changes in the proportion of larval fishes captured in the deep and shallow nets were related to the location and slope of pycnoclines associated with surface fronts. In doing so, we assume that rockfish larvae occur in contiguous and smooth, although not necessarily unimodal, patches.

\section{RESULTS}

During the 4 cruises, 1923 larval and juvenile fishes were captured, $860(44.7 \%)$ of which were rockfish Sebastes spp. Rockfishes were consistently abundant, comprising 33.5 to $76.8 \%$ of the catch for a given cruise. Other species were rare or inconsistently abundant across cruises (see Bjorkstedt 1998). Length data were obtained for 853 of the 860 rockfish larvae. Most rockfish larvae $(83.6 \%)$ were small $(\leq 6 \mathrm{~mm})$ and exhibited little or no sign of flexion; a few $(5 \%)$ were well developed (post-flexion) and exceeded $10 \mathrm{~mm}$, almost all of which (41 of 43) were captured during Cruise IV. We found no difference between size distributions of larvae captured in shallow or deep nets; however, our ability to capture larvae $>8 \mathrm{~mm}$ long appears to have been greater during periods of darkness (data not shown). For this reason, we focus our analysis on the distributions of small $(\leq 6 \mathrm{~mm})$, pre-flexion larvae, and offer more cautious interpretations for larvae ranging in length from 6 to $8 \mathrm{~mm}$.

Upwelling intensity varied substantially among cruises: conditions ranged from strong upwelling to rapid, complete relaxation from upwelling (Figs. 1 \& 2). Such vari- ation notwithstanding, several consistent, large-scale features are visible in satellite imagery coincident with each cruise: (1) cool water recently upwelled from the Point Sur upwelling center; (2) a plume of cool upwelled water extending south from the Point Año Nuevo upwelling center, across the mouth of Monterey Bay, and into the region sampled by our transect (partly obscured by clouds in Fig. 1a); (3) a tongue of warm water extending west and south of Monterey Bay which separated the 2 upwelling plumes; (4) warm oceanic water offshore influenced by coastal upwelling. The placement of our transects resulted in our sampling 3 different 'types' of upwelling fronts: (1) fronts lying near the coast on the northern side of the Point Sur upwelling center, (2) fronts on the oceanic (offshore) side of the distal end of the Point Año Nuevo upwelling plume, and (3) fronts on the coastal (inshore) side of the distal end of the Point Año Nuevo upwelling plume. Nearshore fronts associated with the Point Sur upwelling center were the only type encountered on each cruise; sampling of fronts associated with the Point Año Nuevo plume varied with the position of the plume and the length of the transect (Fig. 1). Particular characteristics of the fronts encountered differed among transects and are described below.

\section{Cruise I: August 1993}

Upwelling-favorable winds temporarily weakened prior to this cruise (Fig. 2a). A series of AVHRR images and independent remote measurements of currents (acoustic Doppler current profiler: Rosenfeld et al. 1995; high-frequency radar: Bjorkstedt 1998; data not shown) indicated poleward flow of cool, recently upwelled water along the coast during wind relaxation. This circulation pattern is typical during relaxation events (Send et al. 1987, Rosenfeld et al. 1994). Observations by both AVHRR and high-frequency radar (Bjorkstedt 1998; data not shown) indicate that upwelling resumed near Point Sur in response to renewed upwelling-favorable winds just prior to sampling.

The transect spanned a frontal region in which density fronts were defined almost entirely by temperature gradients (Fig. 3a-c). It spanned 2 fronts: (1) a front between upwelled water from Point Sur and warmer water just offshore (Figs. 1a \& $3 \mathrm{e}_{\text {; }}$ approximately $10 \mathrm{~km}$ off-

shore), and (2) a front on the
Fig. 2. Wind speeds measured at NDBC Buoy 46042 preceding and during (a) Cruise I, (b) Cruise II, (c) Cruise III, and (d) Cruise IV (dates presented as month/day). Vectors indicate speed and direction towards which the wind was blowing, winds from the northwest (indicated by vectors pointing southeast) are upwelling-favorable along the central California coast. Bar at top of each plot indicates plankton sampling period. For presentation, hourly data were subsampled for every sixth data point (such subsampling did not obscure patterns affecting upwelling dynamics) 
coastal edge of the Point Año Nuevo upwelling plume (Figs. 1a \& 3e; approximately $22 \mathrm{~km}$ offshore). The region between these 2 fronts exhibited complex surface density gradients that included weak frontal signatures at approximately 16 and $19 \mathrm{~km}$ offshore; however, the hydrographic sections do not indicate any fronts in this region (Fig. $3 a-c, e$ ).

The highest densities of larval rockfishes were captured in the shallow net near the inshore upwelling front. Larval rockfishes appear to be distributed in a contiguous patch along the slope of the pycnocline associated with this front (Fig. 3f). Relatively few fish were captured in the Point Año Nuevo upwelling
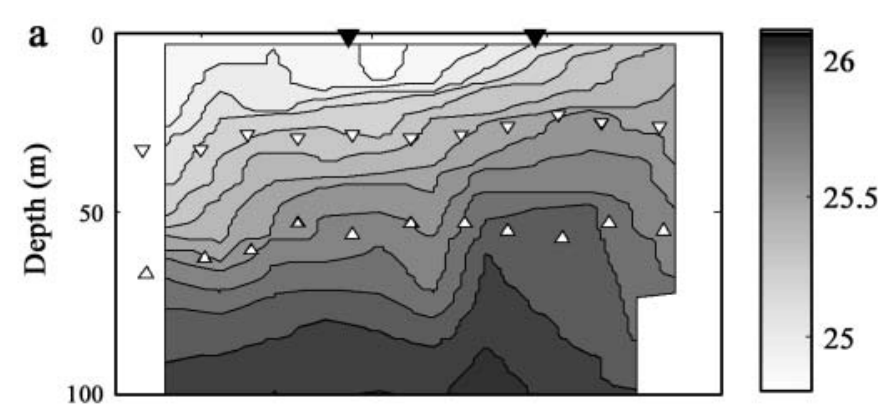

plume; however, the greatest concentration of larger, more developed larval rockfishes was observed at the front marking the coastal edge of this plume (Fig. 3e,f).

\section{Cruise II: May 1994}

Sampling along this transect began soon after the onset of a strong relaxation event, and weak and variable winds persisted throughout sampling (Fig. 2b). A series of quasi-synoptic observations of the frontal zone made during previous crossings of the transect suggests that (1) shoreward advection affected the

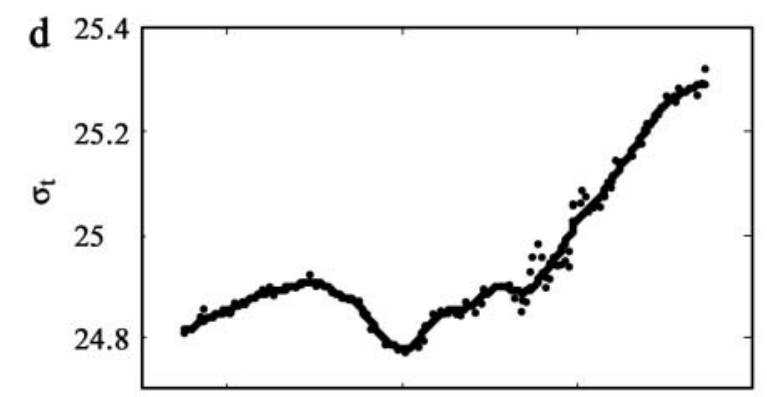

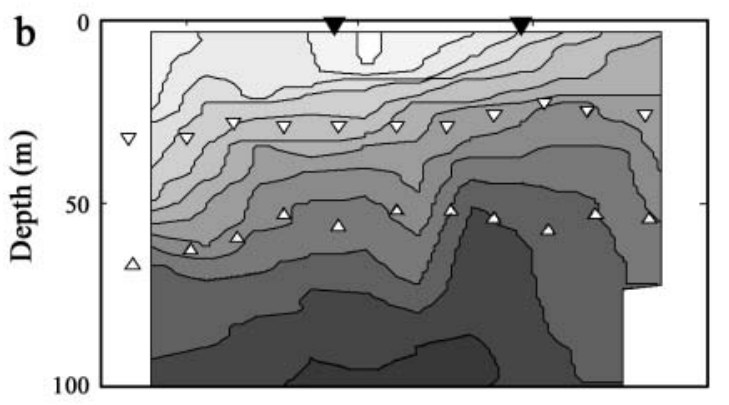
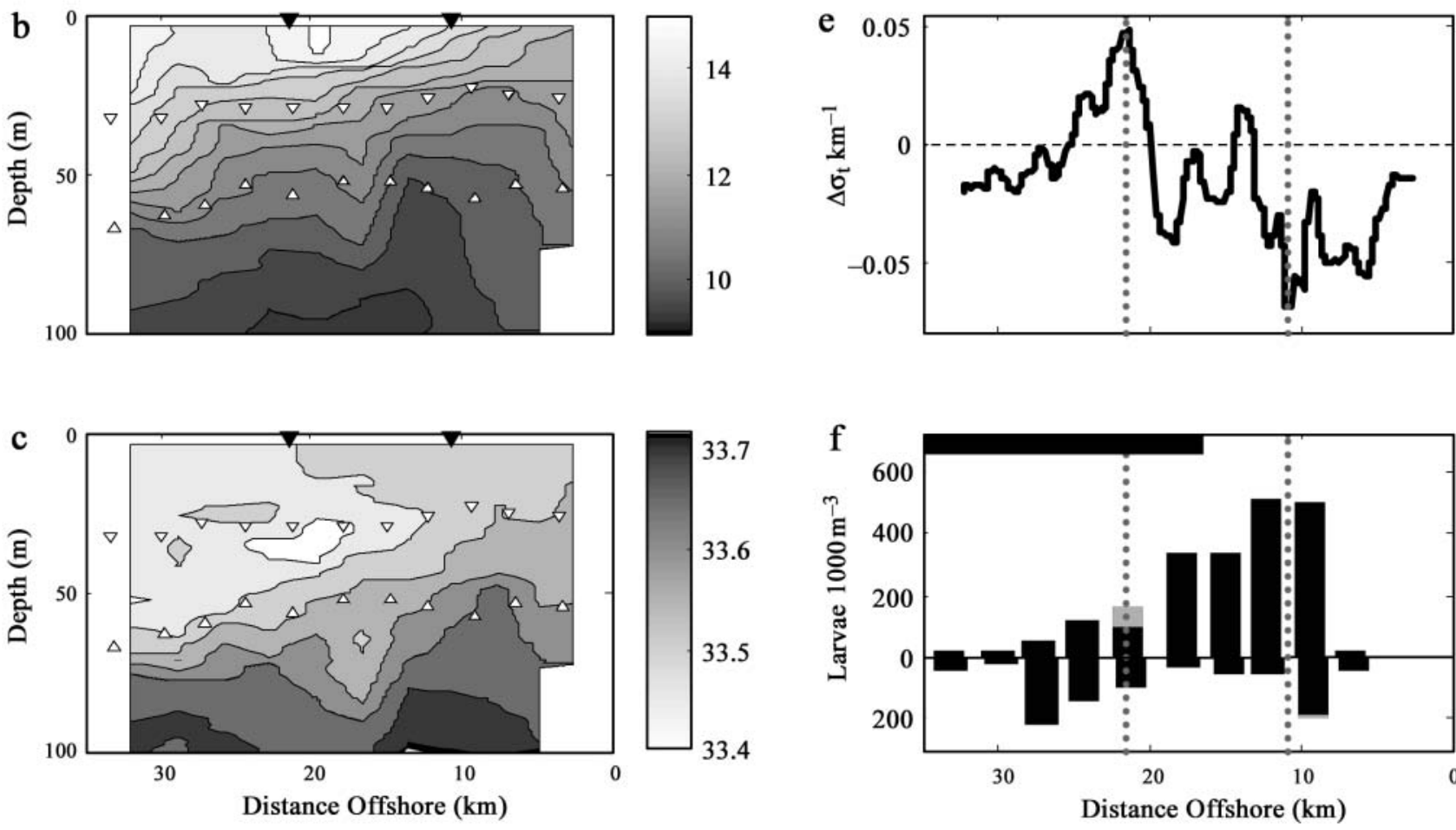

Fig. 3. Physical and biological data for Cruise I. (a) Density, (b) temperature, (c) salinity; open symbols indicate depths of deep ( $\Delta$ ) and shallow $(\nabla)$ nets and filled symbols $(\boldsymbol{\nabla})$ indicate the location of surface fronts. (d) Lowess-smoothed near-surface density. (e) Density gradients derived from smoothed curve in $(d)$; negative gradients indicate effects of upwelling, vertical dotted lines indicate location of surface fronts. (f) Density of rockfish Sebastes spp. larvae of $<6 \mathrm{~mm}$ (dark bars) and 6 to $8 \mathrm{~mm}$ (light bars); ascending bars represent larvae captured in the shallow net, descending bars represent larvae captured in the deep net; bar at the top of the plot identifies stations sampled during darkness, vertical dotted lines indicate location of surface fronts 
upper 50 to $80 \mathrm{~m}$ of the water column, (2) onshore transport was especially rapid in the upper $20 \mathrm{~m}$, and (3) downwelling occurred near the coast (Rosenfeld et al. 1995).

The transect crossed 2 fronts: (1) a strong, nearshore front associated with the Point Sur upwelling center (Figs. 1b \& 4a-e; approximately $8 \mathrm{~km}$ offshore), and (2) a strong front between the upwelling plume from Point Año Nuevo and a poleward-flowing tongue of warm, oceanic water (Figs. 1b \& 4a-e; approximately $27 \mathrm{~km}$ offshore). A weaker front on the coastal side of the Año Nuevo upwelling plume is apparent in the satellite image (Fig. 1b); however, the transect did not cross this front where it formed a clear feature, and appears instead to have skirted the southern edge of warmer water extending from Monterey Bay. Surface density in the region between the

\section{ลี}
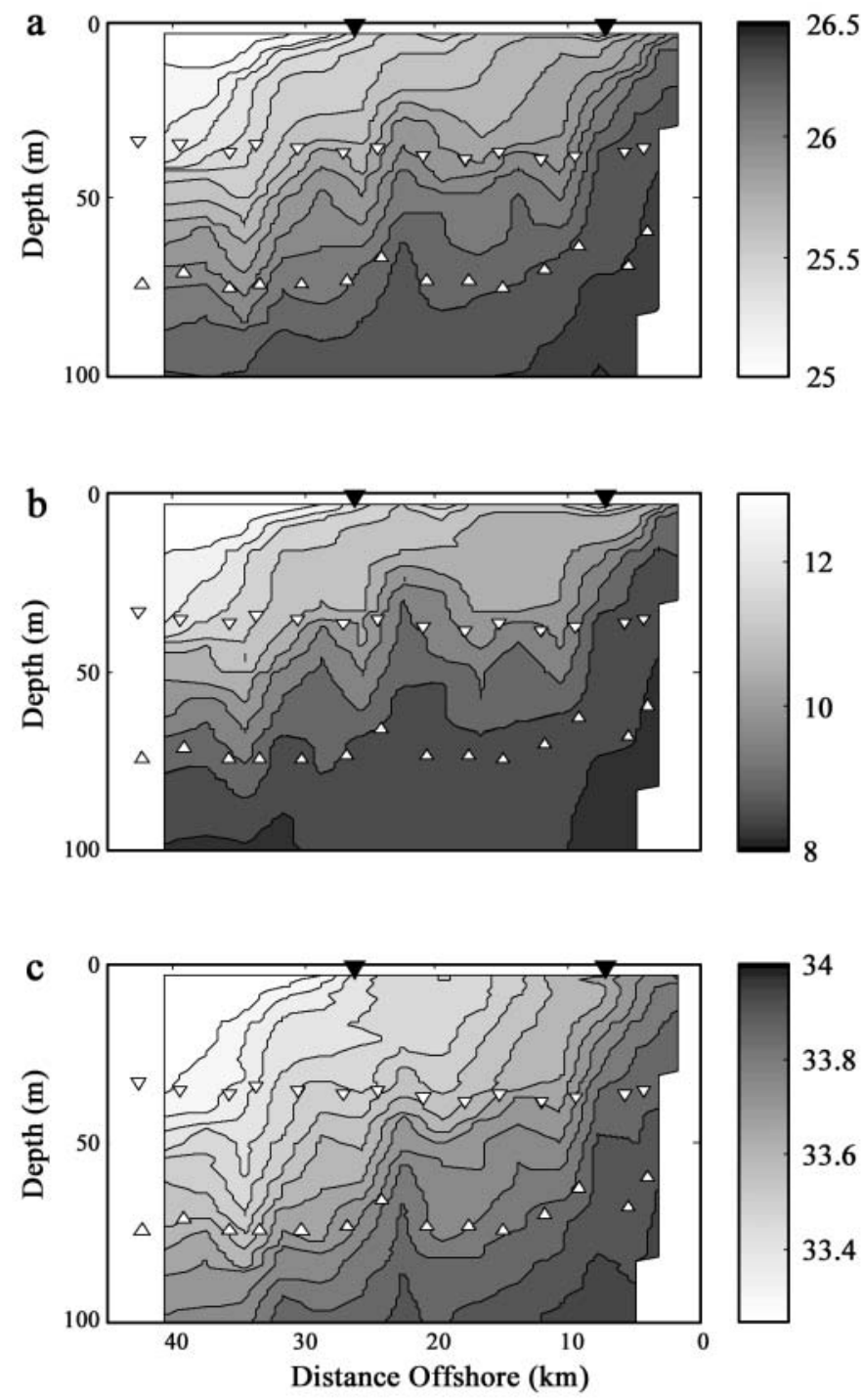

2 strong fronts was highly variable (Fig. 4d), but this variability was not resolved in the hydrographic section (Fig. 4a), and appears to indicate shallow structure along the edge of the warm plume extending from Monterey Bay.

As on Cruise I, larval rockfishes were abundant near surface fronts associated with distinct subsurface structure, and the distribution at each front indicates a patch of larvae oriented along a frontal pycnocline (Fig. 4f). We observed elevated densities of small, preflexion larvae near the surface at both fronts. The highest densities of small larvae occurred near the surface at the nearshore front; larvae occurred in a compact patch that coincided with the steep pycnocline at this front (Fig. 4f). Larger (6 to $8 \mathrm{~mm}$ ), more developed larvae were captured only at stations in the Point Año Nuevo upwelling plume, and occurred at higher densities near
26.5

26

25.5
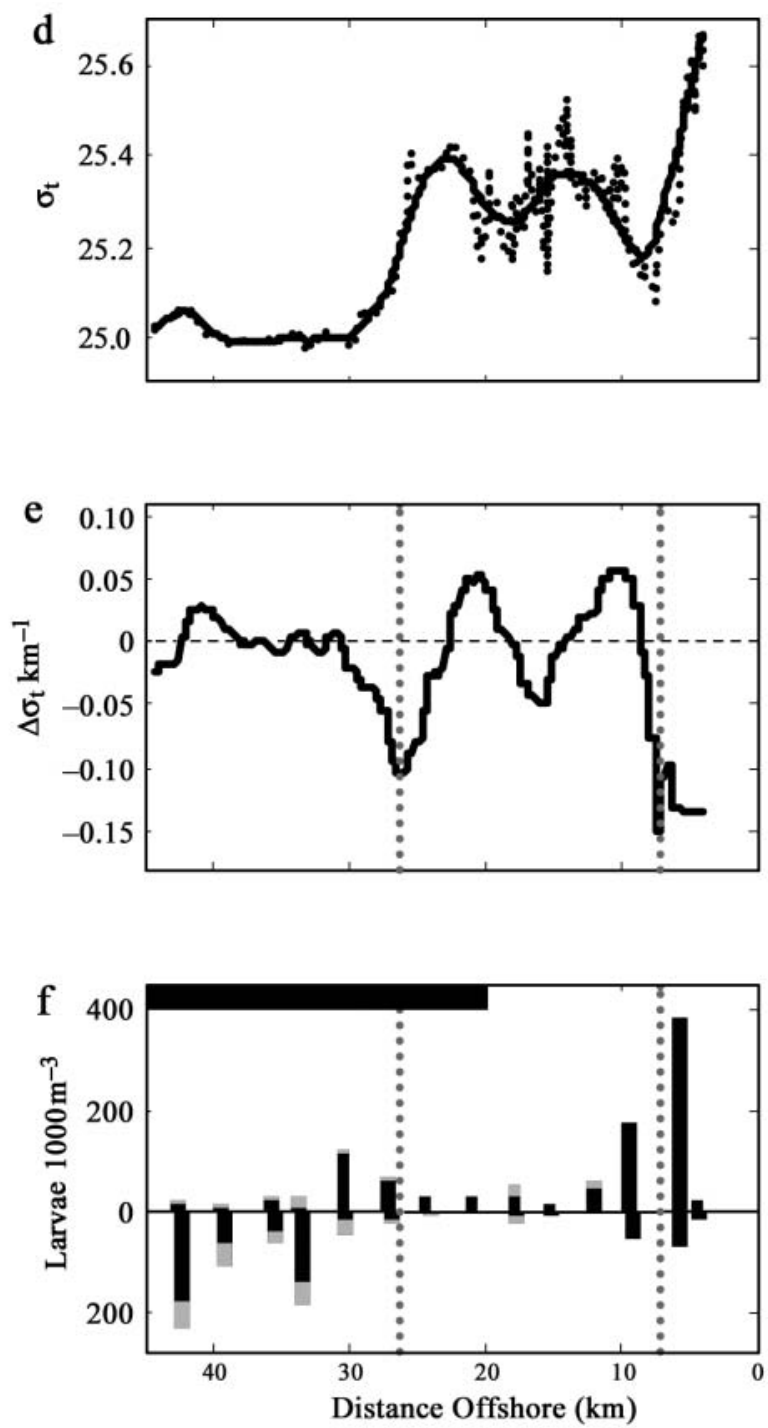

Fig. 4. Physical and biological data for Cruise II (4-5 May 1994). Details as in Fig. 3 
the front on the oceanic side of the plume (Figs. 1b \& 4f). The offshore displacement of the peak density of larval rockfishes relative to the surface front and the rapid shift in the vertical distribution of larval rockfishes between 30 and $33 \mathrm{~km}$ offshore match the structure of this front, i.e. the shallow slope and subsequent rapid increase in depth of the pycnocline offshore of the surface front (Fig. 4a,f). Rockfish larvae were largely absent from the region between the 2 fronts and in warm surface waters $>30 \mathrm{~km}$ from shore (Fig. $4 \mathrm{~b}, \mathrm{f}$ ), but occurred at relatively high density in the layer sampled by the deep net at stations $>33 \mathrm{~km}$ offshore. The transect failed to span the entire offshore patch of rockfish larvae, and we lack hydrographic data that might provide a useful context for the relatively high larval density in the most offshore, deep sample (Fig. 4f).
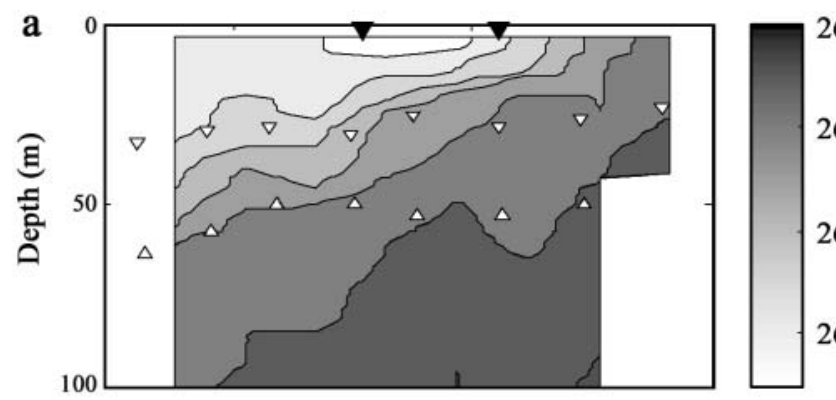

26.6

26.4

26.2

26.0
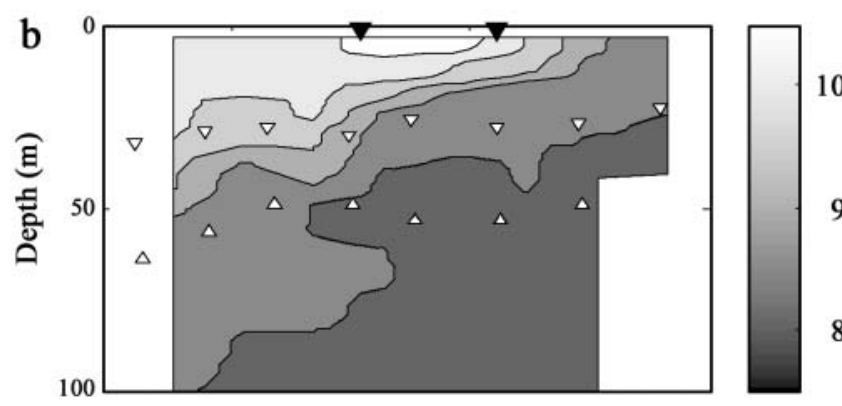

10

9
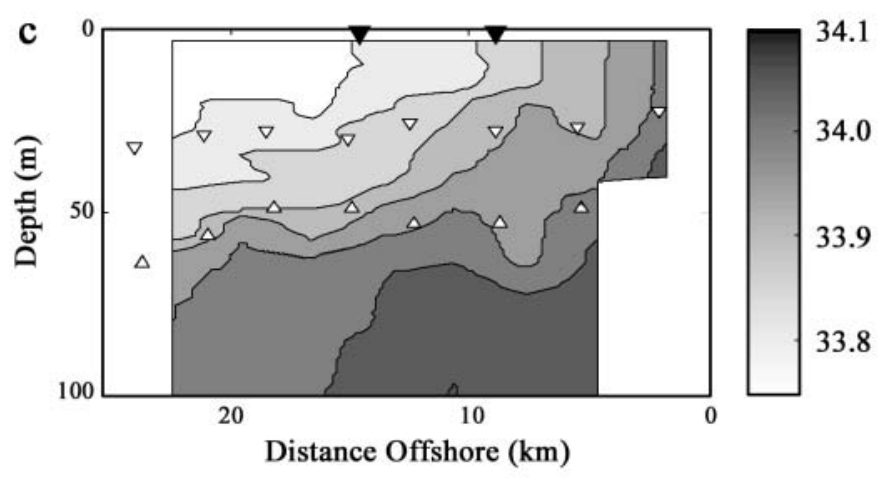

\section{Cruise III: June 1994}

In contrast to the strong relaxation event observed during Cruise II, strong upwelling-favorable winds prevailed for $15 \mathrm{~d}$ prior to and throughout sampling on this transect (Fig. 2c). The transect crossed 2 fronts: (1) an upwelling front bounding the Point Sur upwelling center (Figs. 1c \& 5a-e; approximately $8 \mathrm{~km}$ offshore), and (2) a front on the inshore side of the Point Año Nuevo upwelling plume, which extends completely across the mouth of Monterey Bay (Figs. 1c \& 5a-e; approximately $15 \mathrm{~km}$ offshore). Complex structure in surface density gradients along the transect indicates a third front approximately $5 \mathrm{~km}$ offshore, but this feature does not exhibit substantial subsurface structure (Fig. 5a-e).
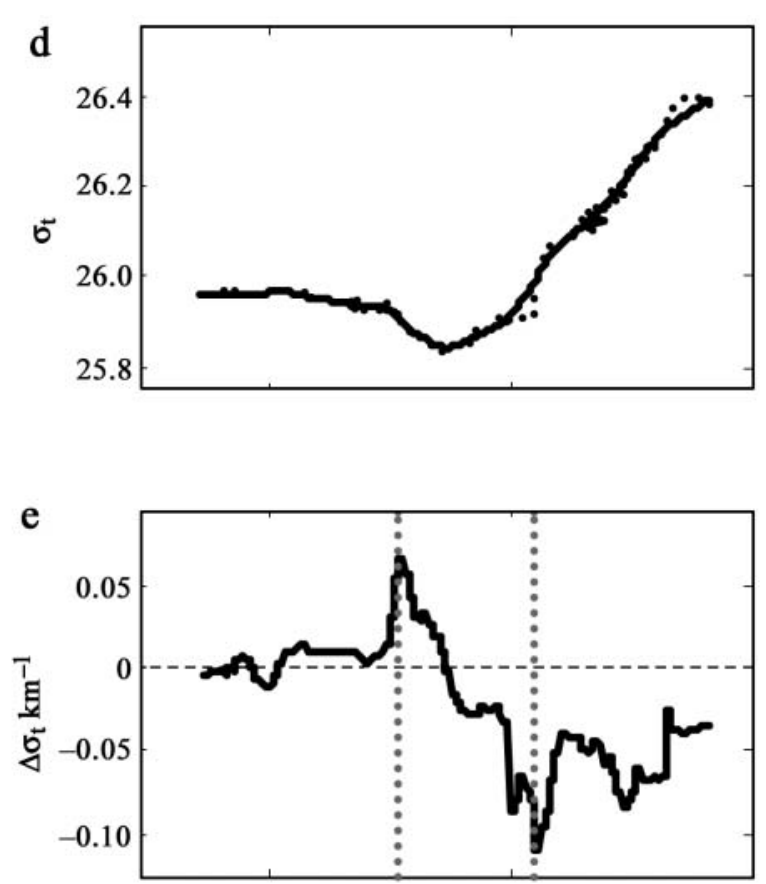

Fig. 5. Physical and biological data for Cruise III (25-26 June 1994). Details as in Fig. 3. * the deeper stratum was not sampled at the most inshore station

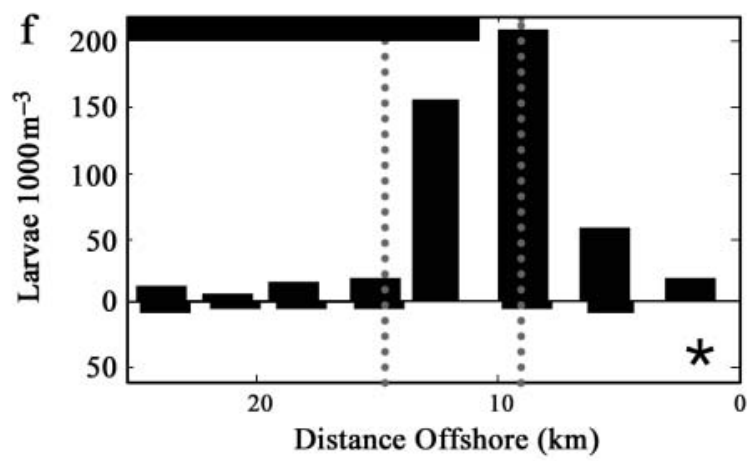


The highest density of larval rockfishes observed on this cruise occurred at the station coincident with the nearshore upwelling front, with substantial numbers of larvae captured at the stations immediately offshore and immediately inshore of that front (Fig. 5e,f). Almost all rockfish larvae captured were small, and only 1 of the larvae captured showed any sign of flexion. Note that the pycnocline associated with the surface front at $8 \mathrm{~km}$ offshore was sampled entirely by the shallow net, and thus our sampling was unable to determine whether the vertical distribution of larvae changed in response to the shallow slope of the pycnocline across the frontal zone (Fig. 5a,f). Very few larvae were captured at depths exceeding 25 to $30 \mathrm{~m}$ (Fig. 5f).
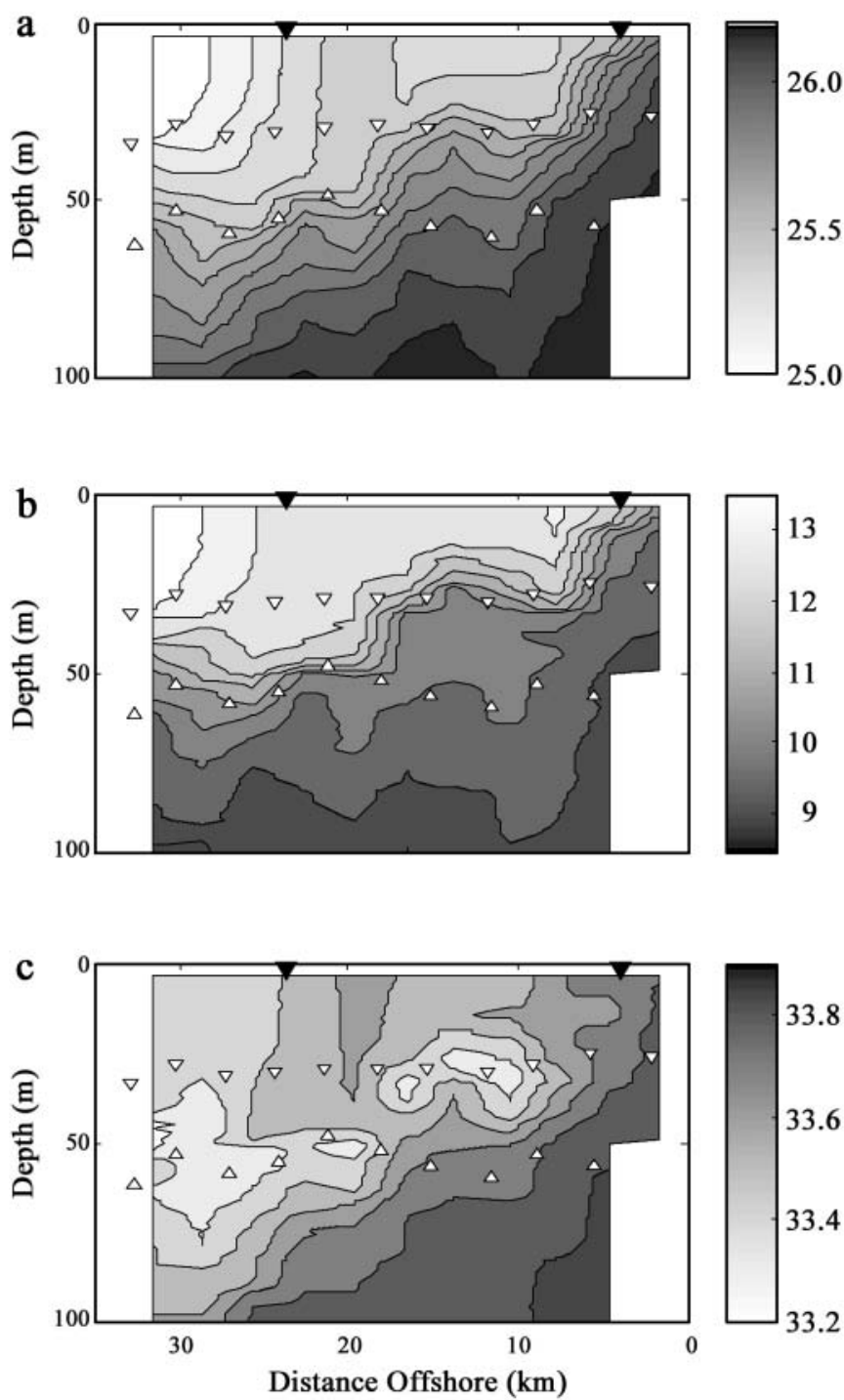

Fig. 6. Physical and biological data for Cruise IV (4-5 August 1994). Details as in Fig. 3. $\star$ the deeper stratum was not sampled

at the most inshore station

\section{Cruise IV: August 1994}

Upwelling favorable conditions preceded and continued through this cruise, save for a brief relaxation event approximately $3 \mathrm{~d}$ prior to sampling (Fig. 2d). This transect spanned 2 fronts: (1) a sharp upwelling front associated with the Point Sur upwelling center (Figs. 1d \& 6a-C; approximately $5 \mathrm{~km}$ offshore); and (2) a front on the offshore side of the Point Año Nuevo upwelling plume (Figs. 1d \& 6a-c; approximately $23 \mathrm{~km}$ offshore). The latter front occurred in a region marked by a deeper surface mixed layer and nearly vertical isopycnals, and exhibited a relatively deep, vertically oriented structure (Fig. 6a). Surface density gradients do not indicate a front on the inshore side of the Point
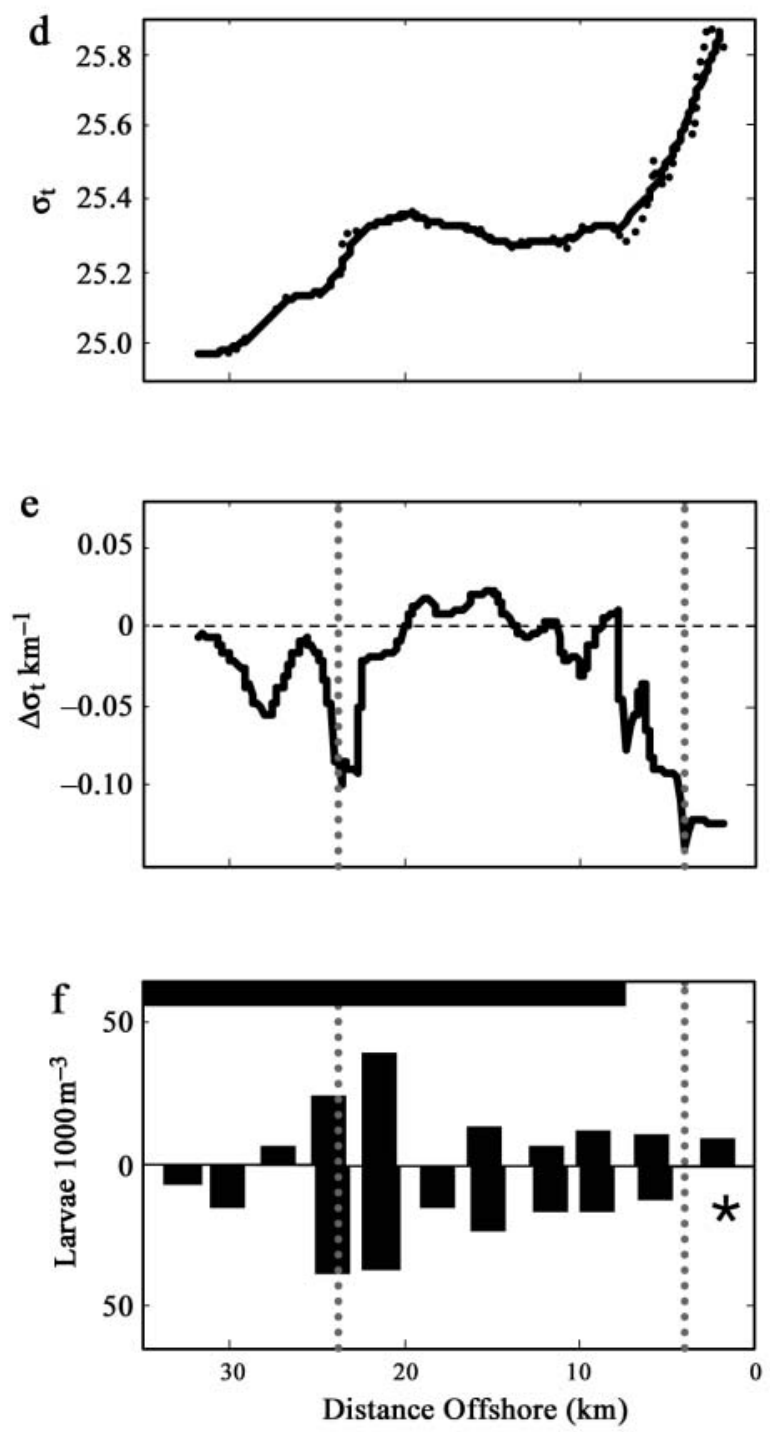
Año Nuevo upwelling plume (Figs. 1d \& 6e); this area is marked by unusual positive correlation between temperature and salinity (i.e. warmer, higher salinity water lying next to cooler, fresher water) in the area just offshore of the nearshore front.

Peak densities of small larval rockfishes were substantially lower on this cruise than densities observed on the previous cruises. Small, preflexion rockfish larvae were most abundant in both shallow and deep nets near the offshore front, and their cross-shelf distribution is truncated at this feature (Fig. 6f). In sharp contrast to previous cruises, a patch of larvae was not observed at the inshore front. As noted at the beginning of 'Results', larger larvae and small juveniles (ranging from 10.2 to $24 \mathrm{~mm}$ in length; data not shown) were far more common on this cruise than on the previous 3 cruises, but the inability of our gear to sample these individuals quantitatively precludes further analysis.

\section{DISCUSSION}

We present evidence, based on data collected under conditions ranging from intense upwelling to complete relaxation, that distributions of larval rockfishes Sebastes spp. are related to the location and crosssectional structure of upwelling fronts off central California. The dataset consists of 4 temporally discrete transects, each of which provides a 2-dimensional 'snapshot' of the larval dynamics, which itself is the integration of larval production, transport, growth and mortality in the context of dynamic, 3-dimensional processes in the coastal ocean. Despite this limited perspective, the combination of our data with inferences on frontal history and the age and source of larvae captured in our samples supports the hypothesis that upwelling fronts affect distributions of early-stage larval rockfishes.

\section{Distribution of larval rockfish in relation to upwelling fronts}

Two general patterns emerge from comparisons between distributions of larval rockfishes and the location and structure of upwelling fronts. First, densities of rockfish larvae at or near upwelling fronts were higher than larval densities at stations away from such fronts. Elevated densities of larval rockfish were observed at 3 of 4 nearshore upwelling fronts (Cruises I-III; Figs. 3 to 5), and at 2 of 2 fronts on the oceanic side of the Point Año Nuevo upwelling plume (Cruises II and IV; Figs. 4 $\& 6)$. Second, changes in the vertical distribution of rockfish larvae, as indicated by changes in the propor- tion of larvae captured in the shallow and deep nets, indicates a shift to deeper distributions at offshore stations that follows the slope of pycnoclines associated with upwelling fronts. Observations that suggest this relation range from larval patches that exhibit gradual increases in depth parallel to frontal pycnoclines (e.g. the inshore front of Cruise I [Fig. 3] and the offshore front of Cruise II [Fig. 4]) to more compact, vertically oriented patches at steeper fronts (e.g. the inshore front of Cruise II [Fig. 4], and the offshore front of Cruise IV [Fig. 6]). These patterns are similar to those reported from surveys of larval fish distributions in other frontal systems (e.g. Kiørboe et al. 1988, Grimes \& Finucane 1991, Kingsford et al. 1991, Munk et al. 1995, Thorrold \& McKinnon 1995, Lochmann et al. 1997).

Note that patches of larval rockfishes were not observed at all fronts; however, this is not surprising given the numerous conditions that must be satisfied for the generation and maintenance of a patch of larvae at a front. For example, low production or high mortality of larval rockfishes near the coast would fail to meet a necessary initial condition for formation of a patch of larvae and might account for the absence of a patch of larval rockfishes at the sharply defined front encountered near the coast during Cruise IV (Fig. 6). Note also that evidence that fronts on the coastal side of the Año Nuevo upwelling plume affect larval distributions was more equivocal than for other fronts encountered in this study. The capture of larger, more developed larvae at such a front during Cruise I (Fig. 3) suggests that such fronts can affect larval distributions, but no such concentration of larvae was observed at a similar front during Cruise III (Fig. 5). Without dismissing the importance of these exceptions, however, we note that we observed no cases in which a substantial patch of larval rockfishes occurred away from a front. Thus, our data support the hypothesis that fronts contribute to, but are not sufficient for the formation and maintenance of patches of larval rockfishes.

The preceding inferences appear to be robust for a number of reasons. First, from a statistical perspective, the generally smooth nature of changes in larval distributions along each transect suggests that withinstation sampling variance is small relative to variation in density at the spatial scales of our study. Thus, in spite of the fact that our data consist of single estimates of larval density at each station, our sampling protocol appears to have been adequate to identify general associations of larval rockfishes and upwelling fronts. Second, since larval fishes exhibit behavioral responses to environmental cues and predator attacks, it is important to note that no potential artifact of our sampling program appears to confound our analysis. Correlation between illumination and front structure arising from the consistent practice of occupying 
sampling stations in a day-tonight, onshore-to-offshore order, raises the possibility that changes in depth of larval rockfishes are related to changes in illumination rather than front structure. However, larval rockfishes do not exhibit typical diel vertical migrations, much less the atypical behavior of descending at night which would be required under this alternative hypothesis (Sakuma et al. 1999). The susceptibility of larval fishes, including larval rockfishes, to capture in plankton nets is also a function of illumination and is expected to increase during twilight and darkness (Morse 1989, McGurk 1992, Sakuma et al. 1999). The effect of increasing capture efficiency would, however, tend to mask the declines in abundance we observed at stations offshore of surface fronts.

Differences in the distribution of larval rockfishes of different sizes and developmental stages highlight the importance of considering the 3-dimensional dynamics of the coastal ocean in studies of larval ecology. In this study, all rockfish larvae captured at the nearshore fronts, save 1, were of the smaller, less developed, and presumably younger class. In contrast, almost all of the larger, more developed, presumably older larvae were captured at stations in the Año Nuevo upwelling plume. We lack direct estimates of age of larvae in our samples (e.g. otolith ring counts); however, rough estimates of larval age based on larval growth rates reported for Sebastes saxicola, S. jordani, and S. goodei suggest that the smaller larvae in our samples had undergone parturition 1 to $10 \mathrm{~d}$ prior to capture, while the larger larvae had been in the plankton for 5 to $25 \mathrm{~d}$ (Laidig et al. 1991, 1996, Sakuma \& Laidig 1995, Ralston et al. 1996). While it is not known whether these growth dynamics adequately represent the growth of the larvae in our samples, the age classes estimated for larvae in our samples are consistent with the expected age of the fronts at which the larvae were captured.

\section{Origins of patches of larval rockfishes at fronts}

Species that undergo parturition primarily during the spring and summer, including some nearshoredemersal species and species of the subgenus Sebastomus that occupy deeper benthic habitats on the inner shelf (Chen 1971, Love et al. 1991, Lenarz et al. 1995), are most likely to comprise the assemblage of larval rockfishes in our samples. Concentrations of larval rockfishes occurred at fronts well offshore of the distribution of adults of these species (which is restricted by the narrow continental shelf off the Big Sur coast) and thus apparently reflect the effects of transport following parturition. The general rarity of larval rockfishes in warmer waters surrounding the upwelling plumes, and differences in the size/developmental stage com- position of larval populations in the Point Sur and Point Año Nuevo plumes support the hypothesis that larval rockfishes at a front originate from adults living in coastal habitats affected by the upwelling center bounded by the front, and not from other regions of the coast.

Our ability to discern conclusively the mechanism(s) that underlie observed distributions of larval rockfishes at upwelling fronts is limited by the 'snapshot' nature of the data at hand, yet our data do not contradict predictions from 2 plausible mechanisms: convergent accumulation and differential mortality. Distributions of larval rockfishes at upwelling fronts resemble general predictions from models of plankton accumulation and retention at fronts (Franks 1992), and are consistent with patterns reported for systems in which convergent accumulation of larval fishes has been demonstrated (e.g. Govoni \& Grimes 1992, Lochmann et al. 1997). Modeling studies and field observations indicate that upwelling fronts exhibit convergent circulation in the upper water column (Federiuk \& Allen 1995, Flament \& Armi 2000); however, evidence that rockfish larvae actively maintain shallow depths - the other condition necessary for accumulation at a convergent surface front (Franks 1992) - is based only on reports that rockfish larvae and juveniles of some species reside in the upper part of the water column (Boehlert et al. 1985, Moser \& Boehlert 1991, Lenarz et al. 1995, Yoklavich et al. 1996, Sakuma et al. 1999). Increased survival of larvae at fronts, presumably supported by convergent accumulation or increased production of suitable prey in frontal zones, might also generate and support elevated densities of larval (and pelagic juvenile) rockfishes at fronts. Whether sufficient time has elapsed since parturition for improved survival of larvae at fronts to generate spatial variation in abundance of larvae is not clear, particularly for the small, preflexion larvae. Differential survival, or perhaps active response to concentrated prey resources, is likely to have a greater influence on the distributions of larger larvae and pelagic juveniles at fronts than on the distributions of smaller larvae.

\section{Implications for continued studies and management of Sebastes spp.}

Our study differs substantially from previous investigations of early life history stages of rockfishes with respect to spatial extent and resolution, season, and species or life history stage of interest. Previous studies have investigated changes in the cross-shelf distribution of early-stage rockfishes in relation to variability in cross-shelf transport (Yoklavich et al. 1996), described the effects of (non-upwelling) oceanic fronts on 
the distribution of larval rockfishes during the winter (Sakuma \& Ralston 1995), and have documented higher densities of pelagic juvenile rockfishes at or near upwelling fronts (Lenarz et al. 1991, Larson et al. 1994, Wing et al. 1998). In contrast, our results demonstrate an association between larval rockfishes and upwelling fronts at a finer spatial scale (a few kilometers horizontally and tens of meters vertically) and at an earlier stage of the life history (the first few days to weeks following parturition) than had been previously documented. Importantly, our results apply to the life history stages that determine recruitment (Woodbury \& Ralston 1991, Ralston \& Howard 1995, Yoklavich et al. 1996). Thus, our results have important implications for future studies of mechanisms that generate variability in rockfish recruitment success.

Rockfish species vary substantially in the seasonality and ecology of their early life histories (WyllieEchevarria 1987, Love et al. 1990, Moser \& Boehlert 1991, Lenarz et al. 1995). Results from a simple comparison, based on this diversity, among rockfish species with respect to patterns of larval survival and exposure of larvae to upwelling point out where our findings might have particular relevance. Recruits from species that undergo parturition during the winter and early spring are drawn from larvae born during discrete pulses of favorable conditions (Woodbury \& Ralston 1991, Yoklavich et al. 1996). Interestingly, these species are exposed to variable, intermittent bursts of upwelling conditions and variation in the timing of the spring transition to sustained upwelling. Such variation is likely to affect the proportion of larval rockfishes that encounter an upwelling front. In contrast, birthdate distributions for the kelp rockfish Sebastes atroviriens, a species which undergoes parturition during the spring and summer, indicate that survivors are drawn from larvae born throughout the parturition season (Lenarz et al. 1995). Larvae of $S$. atroviriens and other species that undergo parturition during the upwelling season are more consistently exposed to upwelling fronts. In combination, these patterns identify upwelling fronts, or some correlated process, as a candidate mechanism to explain seasonal differences in patterns of larval survival among species of rockfishes and to translate intra-annual variability in upwelling dynamics into interannual recruitment variability.

Given the potential for upwelling fronts to influence the ecology of larval rockfish and the results presented here, analysis of frontal dynamics in relation to larval production might provide useful insight into processes that generate recruitment variability (Dixon et al. 1999). Understanding these mechanisms will also help us to understand how coastwide changes in upwelling associated with global climate change (Bakun 1990,
Schwing \& Mendelssohn 1997) will affect recruitment and subsequent population dynamics of rockfishes. From a spatial perspective, understanding how upwelling fronts affect larval survival might contribute to development of spatially explicit models of recruit production which would provide information useful for delineating marine refugia (Allison et al. 1998, Morgan \& Botsford 1998). Important issues remaining to be addressed to evaluate the role of upwelling fronts in rockfish recruitment include (1) whether feeding success, growth and survival (predation) differ between larval rockfish at upwelling fronts and larvae in water masses away from fronts in ways that generate differences in recruitment success, (2) whether fronts affect the distribution and transport of larvae continuously over the course of the pelagic life cycle, and (3) the generality (or the lack thereof) in how upwelling fronts affect larval ecology across species. Regardless of the particular species in the data reported here, the exposure of almost all rockfish species to at least intermittent upwelling during the larval phase suggests that our results have broader relevance and supports further study of the role of upwelling fronts in the early life history of rockfishes.

Acknowledgements. We thank C. Grimes, T. Laidig, R. Larson, S. Ralston, K. Sakuma, and M. Yoklavich for comments and criticism, and 3 anonymous reviewers for comments on an earlier version of the manuscript. We are grateful to $\mathrm{S}$. Alexander, J. Paduan, F. Schwing, and G. Boehlert for discussions of coastal oceanography and the ecology of larval fishes; to T. Anderson and G. Hatcher for their efforts in obtaining and processing the hydrographic data; and to the captains and crew of the RV 'Point Sur' for ably assisting the sampling program. This research was funded under grants from the National Science Foundation to J.R. (OCE-9115876) and L.K.R. (OCE-9116408). E.P.B. gratefully acknowledges support from a National Science Foundation Graduate Research Fellowship and the Earth Systems Program at Stanford University.

\section{LITERATURE CITED}

Ainley DG, Sydeman WJ, Parrish RH, Lenarz WH (1993) Oceanic factors influencing occurrence patterns of young rockfish (Sebastes) in central California: a predator's perspective. Calif Coop Ocean Fish Investig Rep 34:133-139

Allison GW, Lubchenko J, Carr MH (1998) Marine reserves are necessary but not sufficient for marine conservation. Ecol Appl 8:79-92

Bailey KM (1981) Larval transport and recruitment of Pacific hake Merluccius productus. Mar Ecol Prog Ser 6:1-9

Bakun A (1990) Global climate change and the intensification of coastal ocean upwelling. Science 247:198-201

Batteen ML (1997) Wind-forced modeling studies of currents, meanders, and eddies in the California Current system. J Geophys Res C Oceans 102(C1):985-1010

Bjorkstedt EP (1998) Remote sensing and ichthyoplankton ecology of coastal upwelling fronts off central California. PhD dissertation, Stanford University 
Boehlert GW, Gadomski DM, Mundy BC (1985) Vertical distribution of ichthyoplankton off the Oregon coast in spring and summer months. Fish Bull 83:611-621

Breaker LC, Broenkow WW (1989) The circulation of Monterey Bay and related processes. Tech Publ Moss Landing Mar Labs 89-1

Brink KH (1983) The near-surface dynamics of coastal upwelling. Prog Oceanogr 12:233-257

Brink KH, Cowles TJ (1991) The coastal transition zone program. J Geophys Res C Oceans 96(C8):14637-14647

Chen LC (1971) Systematics, variation, distribution, and biology of rockfishes of the subgenus Sebastomus (Pisces, Scorpaenidae, Sebastes). Bull Scripps Inst Oceanogr, University of California Press, Berkeley

Cury P, Roy C (1989) Optimal environmental window and pelagic fish recruitment success in upwelling areas. Can J Fish Aquat Sci 46:670-680

Dengler AT (1985) Relation between physical and biological processes at an upwelling front off Peru $15^{\circ} \mathrm{S}$. Deep-Sea Res 32:1301-1315

Dixon PA, Milicich MJ, Sugihara G (1999) Episodic fluctuations in larval supply. Science 283:1528-1530

Eggleston DB, Armstrong DA, Elis WE, Patton WS (1998) Estuarine fronts as conduits for larval transport: hydrodynamics and spatial distribution of Dungeness crab postlarvae. Mar Ecol Prog Ser 164:73-82

Farrell TM, Bracher D, Roughgarden J (1991) Cross-shelf transport causes recruitment to intertidal populations in central California. Limnol Oceanogr 36:279-288

Federiuk J, Allen JS (1995) Upwelling circulation on the Oregon continental shelf. Part II: simulations and comparisons with observations. J Phys Oceanogr 25:1867-1889

Flament P, Armi L (2000) The shear, convergence, and thermohaline structure of a front. J Phys Oceanogr 30:51-66

Franks PJS (1992) Sink or swim: accumulation of biomass at fronts. Mar Ecol Prog Ser 82:1-12

Govoni JJ, Grimes CB (1992) The surface accumulation of larval fishes by hydrodynamic convergence within the Mississippi River plume front. Cont Shelf Res 12:1265-1276

Graham WM, Largier JL (1997) Upwelling shadows as nearshore retention sites: the example of northern Monterey Bay. Cont Shelf Res 17:509-532

Grantham BA (1997) Coastal upwelling, larval recruitment, and the dynamics of upper intertidal barnacle communities. PhD dissertation, Stanford University

Grimes CB (2001) Fishery production and the Mississippi River discharge. Fisheries (Bethesda) 26:17-26

Grimes CB, Finucane JH (1991) Spatial distribution and abundance of larval and juvenile fish, chlorophyll and macrozooplankton around the Mississippi River discharge plume, and the role of the plume in fish recruitment. Mar Ecol Prog Ser 75:109-119

Grimes CB, Kingsford MJ (1996) How do riverine plumes of different sizes affect fish larvae: do they enhance recruitment? Mar Freshw Res 47:191-208

JPOTS (Joint Panel on Oceanographic Tables and Standards) (1991) Processing of oceanographic station data. UNESCO, Paris

Kean-Howie JC, Pearre S Jr, Dickie LM (1988) Experimental predation by sticklebacks on larval mackerel and protection of fish larvae by zooplankton alternative prey. J Exp Mar Biol Ecol 124:239-259

Kendall AW Jr, Ahlstrom EH, Moser HG (1984) Early life history stages of fishes and their characters. Spec Publ Am Soc Ichthyol Herpetol 1:11-22

Kingsford MJ, Suthers IM (1996a) Dynamic estuarine plumes and fronts: importance to small fish and plankton in coastal waters of NSW, Australia. Cont Shelf Res 14: $655-672$

Kingsford MJ, Suthers IM (1996b) The influence of tidal phase on patterns of ichthyoplankton abundance in the vicinity of an estuarine front, Botany Bay, Australia. Estuar Coast Shelf Sci 43:33-54

Kingsford MJ, Wolanski E, Choat JH (1991) Influence of tidally influenced fronts and Langmuir circulations on distribution and movements of presettlement fishes around a coral reef. Mar Biol 109:167-180

Kiørboe T, Munk P, Richardson K, Christensen V, Paulsen H (1988) Plankton dynamics and larval herring growth, drift and survival in a frontal area. Mar Ecol Prog Ser 44: 205-219

Laidig TE, Ralston S, Bence JR (1991) Dynamics of growth in the early life history of shortbelly rockfish Sebastes jordani. Fish Bull 89:611-621

Laidig TE, Sakuma KM, Nishimoto MM (1996) Description of the pelagic larval and juvenile stripetail rockfish, Sebastes saxicola (family Scorpaenidae), with an examination of larval growth. Fish Bull 94:289-299

Lang KL, Grimes CB, Shaw RF (1994) Variations in the age and growth of yellowfin tuna larvae, Thunnus albacares, collected about the Mississippi River plume. Environ Biol Fish 39:259-270

Larson RJ, Lenarz WH, Ralston SR (1994) The distribution of pelagic juvenile rockfish of the genus Sebastes in the upwelling region off central California. Calif Coop Ocean Fish Investig Rep 35:175-221

Lenarz WH, Larson RJ, Ralston S (1991) Depth distributions of late larvae and pelagic juveniles of some fishes of the California Current. Calif Coop Ocean Fish Investig Rep 32:41-46

Lenarz WH, VenTresca DA, Graham WM, Schwing FB, Chavez F (1995) Explorations of El Niño events and associated biological population dynamics off central California. Calif Coop Ocean Fish Investig Rep 36:106-119

Lochmann SE, Taggart CT, Griffin DA, Thompson KR, Maillet GL (1997) Abundance and condition of larval cod (Gadus morhua) at a convergent front on Western Bank, Scotian Shelf. Can J Fish Aquat Sci 54:1461-1479

Love MS, Morris P, McCrae M, Collins R (1990) Life history aspects of 19 rockfish species (Scorpaenidae: Sebastes) from the Southern California Bight. NOAA Tech Rep NMFS 87:1-38

Love MS, Carr MH, Haldorson LJ (1991) The ecology of substrate-associated juveniles of the genus Sebastes. Environ Biol Fish 30:225-243

Matarese AC, Kendall AW Jr, Bloo DM, Vitner BM (1989) Laboratory guide to early life history stages of Northeast Pacific fishes. NOAA Tech Rep NMFS 80

McGurk MD (1992) Avoidance of towed plankton nets by herring larvae: a model of night-day catch ratios based on larval length, net speed and mesh width. J Plankton Res 14:173-182

Meekan M, Fortier L (1996) Selection for fast growth during the larval life of Atlantic cod Gadus morhua on the Scotian Shelf. Mar Ecol Prog Ser 137:25-37

Morgan LE, Botsford LW (1998) The influence of larval transport and retention on recruitment patterns and the design of harvest refugia for rockfish. In: Yoklavich MM (ed) Marine harvest refugia for West Coast rockfish: a workshop. NOAA Tech Memo NMFS SWFSC-255:41-49

Morgan LE, Wing SR, Botsford LW, Lundquist CJ, Diehl JM (2000) Spatial variability in red sea urchin (Strongylocentrotus franciscanus) recruitment in northern California. Fish Oceanogr 9:83-98 
Morse WW (1989) Catchability, growth, and mortality of larval fishes. Fish Bull 87:417-446

Moser HG, Boehlert GW (1991) Ecology of pelagic larvae and juveniles of the genus Sebastes. Environ Biol Fish 30: 203-224

Moser HG, Charter RL, Smith PE, Ambrose DA, Charter SR, Meyer CA, Sandknop EM, Watson W (1993) Distributional atlas of fish larvae and eggs in the California Current region: taxa with 1000 or more total larvae, 1951-1984. Calif Coop Ocean Fish Investig Atlas 31

Munk P (1993) Differential growth of larval sprat Sprattus sprattus across a tidal front in the eastern North Sea. Mar Ecol Prog Ser 99:17-27

Munk P, Larsson PO, Danielsen D, Moksness E (1995) Larval and small juvenile cod Gadus morhua concentrated in the highly productive areas of a shelf break front. Mar Ecol Prog Ser 125:21-30

Norton J (1987) Ocean climate influence on groundfish recruitment in the California Current. In: Proceedings of the International Rockfish Symposium, Anchorage, Alaska, University of Alaska, Anchorage, (AK Sea Grant Rep 87-2), p 73-99

Pepin P, Dower JF, Leggett WC (1998) Changes in the probability density function of larval fish body length following preservation. Fish Bull 96:633-640

Peterson WT, Miller CB, Hutchinson A (1979) Zonation and maintenance of copepod populations in the Oregon upwelling zone. Deep-Sea Res 26A:467-494

Powell AB, Chester AJ, Govoni JJ, Warlen SM (1990) Nutritional condition of spot larvae associated with the Mississippi River plume. Trans Am Fish Soc 119:957-965

Ralston S (1995) The influence of oceanographic variables on time series of otolith growth in pelagic young-of-the-year rockfish, Sebastes spp. In: Secor DH, Dean JM, Campana $\mathrm{SE}$, Miller $\mathrm{AB}$ (eds) Recent developments in fish otolith research. The Belle W. Baruch Library in Marine Science, No. 19, University of South Carolina Press, Columbia, SC, p 97-118

Ralston S, Howard DF (1995) On the development of yearclass strength and cohort variability in two northern California rockfishes. Fish Bull US Fish Wildl Serv 93: $710-720$

Richardson SL, Pearcy WG (1977) Coastal and oceanic fish larvae in an area of upwelling off Yaquina Bay, Oregon. Fish Bull US Fish Wildl Serv 75:125-145

Rosenfeld LK, Schwing FB, Garfield N, Tracy DE (1994) Bifurcated flow from an upwelling center: a cold water source for Monterey Bay. Cont Shelf Res 14:931-964

Rosenfeld L, Anderson T, Hatcher G, Roughgarden J, Shkedy $Y$ (1995) Upwelling fronts and barnacle recruitment in central California. Monterey Bay Aquarium Res Inst Tech Rep 95-19

Roughgarden J, Pennington JT, Stoner D, Alexander S, Miller K (1991) Collisions of upwelling fronts with the intertidal zone: the cause of recruitment pulses in barnacle populations of central California. Acta Oecol 12:35-51

Sabatés A, Olivar MP (1996) Variation of larval fish distributions associated with variability in the location of a shelfslope front. Mar Ecol Prog Ser 135:11-20

Sakuma KM, Laidig TE (1995) Description of larval and pelagic juvenile chilipepper, Sebastes goodei (family Scorpaenidae), with an examination of larval growth. Fish Bull 93:721-731

Sakuma KM, Ralston RJ (1995) Distributional patterns of late

Editorial responsibility: Thomas Kiørboe (Contributing Editor), Charlottenlund, Denmark larval groundfish off central California in relation to hydrographic features during 1992-1993. Calif Coop Ocean Fish Investig Rep 36:179-192

Sakuma KM, Ralston S, Roberts DA (1999) Diel vertical distribution of postflexion larval Citharichthys spp. and Sebastes spp. off central California. Fish Oceanogr 8:68-76

Schwing FB, Mendelssohn R (1997) Increased coastal upwelling in the California Current System. J Geophys Res C Oceans 102 (C2):3421-3438

Send U, Beardsley RC, Winant CD (1987) Relaxation from upwelling in the Coastal Ocean Dynamics Experiment. J Geophys Res C Oceans 92(C2):1683-1698

Shelton PA, Hutchings L (1982) Transport of anchovy, Engraulis capensis Gilchrist, eggs and early larvae by a frontal jet current. J Cons Int Explor Mer 40:185-198

Shkedy Y, Fernandez D, Teague C, Vesecky J, Roughgarden J (1995) Detecting upwelling along the central coast of California during an El Niño year using HF-radar. Cont Shelf Res 15:803-814

Sims DW, Quayle VA (1998) Selective foraging behavior of basking sharks on zooplankton in a small scale front. Nature 393:460-464

St John MA, Lund T (1996) Lipid biomarkers: linking the utilization of frontal plankton biomass to enhanced condition of juvenile North Sea cod. Mar Ecol Prog Ser 131:75-85

Taggart CT, Drinkwater KF, Frank KT, McRuer J, LaRouche P (1989) Larval fish, zooplankton community structure, and physical dynamics at a tidal front. Rapp PV Reun Cons Int Explor Mer 191:184-194

Thorrold SR, McKinnon AD (1995) Response of larval fish assemblages to a riverine plume in coastal waters of the central Great Barrier Reef lagoon. Limnol Oceanogr 40: $177-181$

Traganza ED, Conrad JC, Breaker LC (1981) Satellite observations of a cyclonic upwelling system and giant plume in the California Current. In: Richards FA (ed) Coastal upwelling. American Geophysical Union, Washington, DC, p 228-241

Traganza ED, Redalie DG, Garwood RW (1987) Chemical flux, mixed layer entrainment and phytoplankton blooms at upwelling fronts in the California coastal zone. Cont Shelf Res 7:89-105

Wing SR, Botsford LW, Largier JL, Morgan LE (1995a) Spatial structure of relaxation events and crab settlement in the northern California upwelling system. Mar Ecol Prog Ser 128:199-211

Wing SR, Largier JL, Botsford LW, Quinn JF (1995b) Settlement and transport of benthic invertebrates in an intermittent upwelling region. Limnol Oceanogr 40:316-329

Wing SR, Botsford LW, Ralston SV, Largier JL (1998) Meroplanktonic distribution and circulation in a coastal retention zone of the northern California upwelling system. Limnol Oceanogr 43:1710-1721

Woodbury D, Ralston S (1991) Interannual variation in growth rates and backcalculated birthdate distributions of pelagic juvenile rockfish (Sebastes spp.) off the central California coast. Fish Bull 89:523-533

Wyllie-Echevarria T (1987) Thirty-four species of California rockfishes: maturity and seasonality of reproduction. Fish Bull 85:229-250

Yoklavich MM, Loeb VJ, Nishimoto M, Daly B (1996) Nearshore assemblages of larval rockfishes and their physical environment off central California during an extended El Niño event 1991-1993. Fish Bull 94:766-782

Submitted: January 14, 2002; Accepted: April 5, 2002

Proofs received from author(s): September 19, 2002 